\title{
Role of Silicon on Enhancing Disease Resistance in Tropical Fruits and Vegetables: A Review
}

\section{Darshani Weerahewa* and Kosala Somapala}

Department of Botany, The Open University of Sri Lanka

\begin{abstract}
Silicon ( $\mathrm{Si}$ ) has proven to enhance disease resistance in a wide range of tropical fruits and vegetables. It has been used in controlling various diseases: mildews, rots, moulds, wilt, blight, anthracnose and leaf spots. However, the highest number of records was available on reducing diseases of powdery mildews on fruits and vegetables belonging to the family Cucurbitaceae. Siliconmediated defense responses in plant pathosystems are mainly attributed to the physical resistance, which involves reduced penetrability and/or increased hardness and abrasiveness of plant tissues because of silica deposition. The main mechanism is the chemical resistance, which involves chemical defenses to pathogen attack through the enhanced production of defensive enzymes and the production of antifungal compounds such as phenolic metabolism products, phytoalexins and pathogenesis related proteins. Silicon has been applied as soluble silicates to the substrate or to soilless media at pre-harvest level on reducing disease susceptibility. Post-harvest dips of fresh produce in silicate solutions and use of $\mathrm{Si}$ combined with a biocontrol agent are other aspects of silicon application in controlling diseases in fruits and vegetables.
\end{abstract}

Keywords: Silicon application, plant pathogens, defense responses

\section{Introduction}

Silicon ( $\mathrm{Si})$ is taken up by plants at concentrations similar to the

*Correspondence should be addressed to Dr. Darshani Weerahewa Department of Botany, The Open University Sri Lanka, Nawala, Sri Lanka (Email: hlwee@ou.ac.lk) 
essential nutrients. However, persistent chemical fertilization and crop removal from the field tend to the depletion of Si availability for plants. As a result, Si has been identified as a limiting factor for Siaccumulating plants, as well as for the plants grown in soils deficient with Si (Epstein, 1999). The beneficial effects of Si have been observed in a wide variety of plant species including enhanced insect and disease resistance, reduced mineral toxicity, increased photosynthetic activity, superior nutrient imbalance, and enhanced drought and frost tolerance (Ma, 2004). Though silicon has not been recognized as an essential element for plant growth, plants deprived of $\mathrm{Si}$ are often weaker structurally and more prone to abnormalities of growth, development and reproduction. Silicon is considered as the only nutrient element which is not detrimental when collected in excess in plants (Ma and Takahashi, 2002).

Silicon is absorbed to plants from the soil solution with concentrations ranging from 0.1 to $0.6 \mathrm{mM}$ as monosilicic acid, $\mathrm{H}_{4} \mathrm{SiO}_{4}$ (Ma and Takahashi, 2002). The Si concentrations vary widely in above ground plant parts, ranging from 0.1 to $10.0 \%$ on dry weight basis (Liang et al., 2005). Plant species are considered as $\mathrm{Si}$ 'Accumulators' when the concentration of Si of its dry weight is greater than $1 \%$. 'Intermediates' have $\mathrm{Si}$ amounts less than $0.1 \%$ in their biomass. Plants containing Si concentration below $0.5 \%$ of the bio mass are considered as 'Excluders' (Ma and Takahashi, 2002).

Silicon has been found to effectively control many of the diseases found in tropical fruits. However, diseases, such as blue mould and gray mould were reduced in fruits grown in temperate countries.

Silicon has been applied as a form of pre-harvest or post-harvest application, or root or foliar application. The research has also been done on silicon application in combination with yeast or phosphorus acid or hot water treatment. Different sources of silicon i.e. sodium silicate, calcium silicate, calcium silicate, rice hull (raw or partially burnt) have been used as sources for providing Si to the fruits and vegetables.

The following sections describe the disease control by application of silicon in tropical fruits and vegetables. Some records were available on reducing anthracnose disease in tomato and capsicum grown in 
Sri Lanka.

\section{Silicon and mildew diseases}

\section{Powdery mildew}

A noticeable inhibitory effect against powdery mildew has been reported by silicon application in cucurbits. A majority of the alleviative effects studies has been accounted in cucumber powdery mildew caused by Sphaerotheca fuliginea (Samuels et al., 1993; Menzies et al., 1991; 1992; Fawe et al., 1998; JungSup et al., 2000; Schuerger and Hammer, 2003; Wei et al., 2004; Liang et al., 2005; QiuJu et al., 2009; Buttaro et al., 2009; Wolff et al., 2012) and by Sphaerotheca fuliginea (Liang et al., 2005). Effective suppression of the disease could be observed in some other cucurbits such as melons caused by $S$. fuliginea and/or Erysiphe cucurbitacearum (Menzies et al., 1992; Yurong et al., 2005; Guo et al., 2005; Chen et al., 2010). Root applied $\mathrm{Si}$ induced the resistance against Podosphaera xanthii reducing the disease severity in melon. Supplying silicon in nutrient solutions reduced the severity and incidence of powdery mildew in two varieties of melon, carosello and barattiere (Buttaro et al., 2009). Furthermore, powdery mildew in zucchini squash caused by E. cichoracearum and Podosphaera xanthii pumpkin caused by P. xanthii (Heckman et al., 2003) was lessened by pre-harvest silicon application.

Palmer et al. (2006) reported that powdery mildew caused by Sphaerotheca aphanis in strawberry can effectively be suppressed by foliar application of potassium silicate. Silicon had beneficial effects on strawberry plants and may serve as an alternative to fungicides for controlling powdery mildew when supplied as a foliar spray of potassium and sodium silicate. Kanto et al. $(2004,2007)$ and Wang and Galletta (1996) have recorded similar results about the strawberry- powdery mildew patho-system. However, root application of silicon could not reduce the disease severity in strawberry (Bowen et al., 1992). Similar suppressive effects of Si against Uncinula necator were stated by Reynolds et al. (1996) and Blaich and Grundhofer (1998) in grapes. Foliar applied potassium silicate was found to exhibit inhibitory effects on Leveillula taurica, 
the powdery mildew causing fungi in tomato (Yanar et al., 2013).

\section{Downy mildew}

Foliar application of Si suppressed cucumber downy mildew caused by Pseudoperonospora cubensis (Yu and Du, 2009; Yu et al., 2010). Garibaldi et al. (2012) discovered that electrical conductivity and potassium silicate together significantly influenced downy mildew (Bremia lactucae) incidence and severity on lettuce in hydroponic system. The best results, in terms of disease control, were given by the addition of potassium silicate to the $0.95 \mathrm{~g}^{-1} \mathrm{NaCl}$ solution.

\section{Silicon and rot diseases}

\section{Fruit rots}

\section{Alternaria fruit rot}

The synergistic effects of biocontrol yeasts Cryptococcus laurentii and Rhodotorula glutinis combined with silicon against Alternaria fruit rot (Alternaria alternate) have been investigated in jujube fruit (Chinese date: Zizyphus jujuba). Combinations of $C$. laurentii and $R$. glutinis with $\mathrm{Si}$ were found to be most effective in controlling the diseases caused by A. alternata in jujube fruit (Shiping et al., 2005). Post harvest sodium silicate treatments could resist the growth of $A$. alternate in pingguoli pear (Guo et al., 2003).

\section{Other fruit rots}

The susceptibility to pink rot caused by Trichothecium roseum was shown to be decreased by postharvest $\mathrm{Si}$ application in muskmelon (Li et al., 2012), Chinese cantaloupe (Yurong et al., 2003; Guo et al., 2007) and hami melon (Bi et al., 2006). Yang et al. (2010) have revealed synergistic effects of silicon on disease control in apple brown rot (Monilinia fructicola). Foliar application of Si was effective in controlling tomato fruit rot caused by Phytophthora capsici (Mersha et al., 2012)

\section{Root rots}

\section{Pythium root rot}

It was stated that $\mathrm{Si}$ is effective in controlling root rot in cucumber 
caused by Pythium ultimum and $P$. aphanidermatum (Cherif and Belanger, 1992; Chérif et al., 1994a, 1994b). However, Heine et al. (2007) revealed that the incidence of root rot in cucumber, tomato and bitter gourd caused by $P$. aphanidermatum could not be controlled by Silicon application.

\section{Phytophthora root rot}

Silicon was effective in controlling cucumber root rot caused by Phytophthora melonis (Mohaghegh et al., 2011). In hydroponic experiments, Khoshgoftarmanesh et al. (2012) have demonstrated that Phytophthora root rot $(P$. drechsleri) in cucumber could be alleviated by $\mathrm{Si}$ application. Bekker et al. (2007) found the efficacy of root application of potassium silicate on controlling the disease $(P$. cinnamomi) in avocado.

\section{Fusarium root rot}

Due to the application of Si to tomato seedlings, the disease severity of root rot caused by Fusarium oxysporum f.sp.radicis-lycopersici was reduced. This inhibitory effect was due to the delaying in onset and initial infection of roots and the movement of the pathogen from roots to stems (Huang et al., 2011). Silicon was also reported to be effective to suppress the disease resulted by $F$. solani in tomato (ElSamman et al., 2000). Fusarium oxysporum f.sp.radiciscucumerinum, the causative fungi of cucumber root rot, could be effectively controlled by soil applied Si (Safari et al., 2012). The alleviative role of $\mathrm{Si}$ on the disease was also recorded in other cucurbits in fact hamimelon: F. semitectum, cantaloupe: Fusarium spp. and rock melon: F. oxysporum f. Sp. Melonis (Bi et al., 2006; Liu et al., 2009; Kumar and McConchie, 2010)

\section{Pink rot}

Si application has also been shown to decrease susceptibility to pink rot caused by Trichothecium roseum in muskmelon (Li et al., 2012), Chinese cantaloupe (Guo et al., 2007; Yurong et al., 2003) and hami melon (Bi et al., 2006). 


\section{Banana root rot}

Using the image analysis program WinRHIZO, Vermeire et al. (2011) exhibited that root-rot fungi Cylindrocladium spathiphylli infection in banana could be mitigated. The $\mathrm{Si}$ amendment also alleviated growth reduction caused by the pathogen.

\section{Silicon and mould diseases}

\section{Blue mould}

Ebrahimi et al. (2012) explained that postharvest silicon application was more effective in reducing the lesion diameter of blue mould decay of apples caused by Penicillium expansum in combination with the yeast, Torulaspora delbrueckii than using $\mathrm{Si}$ or T. delbrueckii alone. In a consequent study, Ebrahimi et al. (2013) discovered the efficacy of controlling the disease triggered by applying $\mathrm{Si}$ together with the yeast, Metschnikowia pulcherrima. Farahani et al. (2012) suggested that the yeast, Candida membranifaciens combined with different concentrations of silicon, improved the effectiveness of yeast in controlling the disease in apple. Similar results have been observed by Farahani et al. (2013) by dual application of silicon and the yeast, Pichiaguillier mondii in apples. Postharvest dips of apples in potassium silicate solution (Moscoso-Ramírez and Palou, 2014) and in Si added hot water (Etebarian et al., 2013) were other means of suppressing the disease. Combinations of the yeast species, Cryptococcus laurentii and Rhodotorula glutinis along with $\mathrm{Si}$ was more successful in controlling blue mould caused by $P$. expansum on jujube fruit (Shiping et al., 2005).

\section{Green mould}

Silicon has been reported to prevent the incidence of green mould caused by Penicillium digitatum in a number of citrus fruits (Abraham, 2010; Liu et al., 2010). Mkhize et al. (2013) revealed that pre- and post-harvest $\mathrm{Si}$ amendments could upsurge the resistance of lemon to $P$. digitatum. Postharvest dips of potassium silicate before inoculation the same pathogen on oranges significantly reduced the severity of green mould (Moscoso-Ramirez and Palou, 2014). 


\section{White mould}

In bean, disease incidence and severity of white mould (Sclerotinia sclerotiorum) were significantly reduced by $52 \%$ and $73 \%$, respectively, via applying $\mathrm{Si}$ as calcium silicate together with calcium chloride (PaulaJúnior et al., 2009).

\section{Gray mould}

On increasing the quality of organically grown strawberry, Prokkola and Kivijärvi (2008) found that silicon is effective in controlling gray mould (Botrytis cinerea), when applied as a combination with Trichoderma spp. in two weeks interval until harvested. Soil application of liquid potassium silicate to cucumber plants notably reduced the incidence of gray mould caused by B. cinerea (O'Neil, 1991). In contrast, post-harvest $\mathrm{Si}$ application was found to be ineffective for controlling gray mould $(B$. cinerea) in strawberry (Lopes et al., 2014).

\section{Silicon and wilt disease}

\section{Bacterial wilt}

Soil supplied silicon enhanced the resistance in tomato plants against Ralstonia solanacearum, the causing agent of bacterial wilt (Ghareeb et al., 2011). Silicon amendments were also reported to reduce the disease incidence in tomato when applied to soil (Dannon and Wydra, 2004; Diogo and Wydra, 2007; Kiirika et al., 2013). However, dual application of silicon and a rhizobacteria strain Bacillus pumilis against the disease was not effective as same as application of silicon alone in tomato (Kurabachew and Wydra, 2014).

Recently, it was revealed that $\mathrm{Si}$ mediated resistance in tomato against $R$. solanacearum was associated with the changes of soil microorganism amount and soil enzyme activity (Wang et al., 2013). The uptake of Si was significantly increased in the Si-treated tomato plants, where the Si content was higher in the roots than that in the shoots. The results showed that exogenous $2.0 \mathrm{mM}$ Si treatment 
reduced the disease index of bacterial wilt by $19.18 \%$ to $52.7 \%$. Si supply significantly increased soil urease and soil acid phosphatase activity under pathogen-inoculated conditions. After $R$. solanacearum inoculation, $\mathrm{Si}$ amendments significantly increased the amount of soil bacteria and actinomycetes and reduced soil fungi/soil bacteria ratio. The results suggested that $\mathrm{Si}$ amendment is an effective approach to control $R$. solanacearum, and Simediated resistance in tomato against $R$. solanacearum is associated with the changes of soil microorganism amount and soil enzyme activity (Wang et al., 2013). Silicon amendment significantly reduced bacterial wilt incidence of tomato grown in peat substrate (Diogo and Wydra, 2007) and hydroponic culture (Dannon and Wydra, 2004).

\section{Fusarium wilt}

Fortunato et al. (2012) revealed that supplying Si to banana plants at seedling stage had a great potential in reducing the intensity of Fusarium wilt caused by Fusarium oxysporum. The suppressive effect of $\mathrm{Si}$ on the disease in cucumber caused by Fusarium oxysporumf.sp.radicis- cucumerinum was also reported by Safari et al. (2012).

\section{Silicon and blight}

\section{Phytophthora blight}

In cucumber, root applied liquid potassium silicate notably reduced the incidence of stem blight caused by Didymella bryoniae (O'Neil, 1991). Silicon accumulation in roots followed by $\mathrm{Si}$ supply could potentially reduce the severity of Phytophthora blight caused by Phytophthora capsici while enhancing the plant development in bell pepper (French-Monar et al., 2010) as well as in pepper (Lee et al., 2004). Foliar application of soluble silicon could efficiently control the disease in tomato caused P. capsici (Mersha et al., 2012). In addition, silicon nutrition enhanced the resistance to stem blight caused by Phomopsis asparagi in two asparagus cultivars, UC157 and Gynlim (Lu et al., 2008). 


\section{Stem blight}

Application of liquid potassium silicate through a separate set of drip lines to cucumbers grown on rockwool slabs significantly reduced the incidence of stem blight caused by Didymella bryoniae, and appeared to reduce that of those caused by B. cinerea (O'Neil, 1991).

\section{Silicon and anthracnose}

Yang et al. (2008) have revealed that it could control the occurrence of anthracnose (Colletotrichum higginsianum) of flowering Chinese cabbage (Brassica campestris L.) on Si application. Injecting soluble silicon into trees prior to harvest significantly decreased the severity and incidence of postharvest anthracnose in avocado while, a combination of soluble silicon and phosphorous acid was not that effective in controlling of anthracnose (Anderson et al., 2005). The disease in avocado could similarly be controlled effectively by postharvest application of soluble silicon (Bosse et al., 2011). The susceptibly to the disease (C. gloesporioides) in tomato was mitigated by soil application of sodium silicate (David and Weerahewa, 2012; Weerahewa and David 2015), and application of partially burnt rice hull (Somapala et al., 2015). Root and shoot applied Si was proven to be an effective way of reducing the disease severity caused by $C$. gloesporioides in Capsicum annuum L. 'Muria F1' (Jayawardana et al., 2014, 2015). The significant reduction of anthracnose disease was observed in capsicum grown in simplified hydroponics system incorporated with raw rice hull as a supplement of silicon(Jayawardana et al., 2016).Moreover, Si induced the resistance against Fitopatologia Brasileira and C. lindemuthianum in bean (Moraes et al., 2006; Polanco et al., 2012, 2014).

\section{Silicon and Leaf spot}

Foliar application of potassium silicate, as a source of soluble silicon, decreased angular leaf spot (Pseudocercospora griseola) severity on beans at more alkaline $\mathrm{pH}$ (Rodrigues et al., 2010). 


\section{Banana sigatoka}

The effect of silicon uptake on the susceptibility of banana to Mycosphaerella fijiensis, the causative pathogen of black sigatoka disease was investigated by Kablan et al. (2012). It was revealed that Si supply could alleviate the disease in the plants grown both in hydroponic culture system and in pots filled with compost.

\section{Underlying mechanism/s of disease resistance mediated by silicon}

There are mainly two methods by which $\mathrm{Si}$ induces the resistance in plants against infections. It is either by the chemical defense owing to the physical defense developed due to $\mathrm{Si}$ deposition on plant tissues preventing the pathogen penetration and/or by synthesis of anti-pathogenic compounds. In addition, systemic acquired resistance (SAR) was found to be induced upon silicon application in fruits and vegetables.

\section{Mechanical Resistance}

Silicon has been shown to be effective in mitigating biotic stress by means of mechanical resistance in fruits and vegetables in a number of studies. Pre-harvest or post-harvest silicon application had shown a great potential in controlling diseases by inhibiting or delaying the growth and development of the mycelium of the pathogen (Samuels et al., 1993; Bowen et al., 1992; Hu et al., 2008; $\mathrm{Yu}$ and Du, 2009; Abraham, 2010) due to silicon deposition at infection sites and hyphae (Reynolds et al., 1996)

Si application strongly inhibited spore germination, germ tube formation and development of appresoria and possibly the penetration of fungi were hindered. It was hypothesized that Si inhibits fungal disease by physically inhibiting fungal penetration peg dispersion of the epidermis (Menzies et al., 1991a, 1991b; Bowen et al., 1992; Yurong et al. 2005; Kanto et al., 2007; Liu et al., 2010). Si was translocated laterally through the leaf and surrounded the appressoria of $U$. necator upon foliar application of Si. Plant leaves that were fed with $\mathrm{Si}$ via roots showed a similar deposition of $\mathrm{Si}$ surrounding the appressoria making a rigid physical barrier for penetration (Bowen et al., 1992). 
It has also been found that the trichome bases on the epidermis tend to become silicified (Belanger et al., 1995; Samuels et al., 1993; Chérif et al., 1994a) changing their morphology against infections. Si deposition in leaf hairs suppressed the fungal penetration as a result of increased density and length (Fatema et al., 2011). Penetration peg incursion was found to be constrained by rapid $\mathrm{Si}$ deposition at the external openings like stomata of the leaves (Guo et al, 2007). A fast silicification at intercellular spaces, cuticle layer (Kanto et al., 2007) and along the space between the exocarp and mesocarp (Guo et al., 2007) made it more difficult for pathogen penetration and dispersion. Powdery mildew infected leaf cells of silicate treated plants were exhibited to have extensive silica polymerization enhancing the thickness against the fungi in the halo region surrounding the site of fungal penetration (Menzies et al., 1991b). Altered surface morphology of the host cell walls was observed adjacent to the germinating hyphae (Samuels et al., 1993). Deposition of silicon in host cell walls, papillae, around the haustorial neck and in-between the host cell wall and plasma membrane enhanced induced structural defense reactions (Samuels et al., 1994) against $S$. fuliginea.

Changes in the pectic polysaccharide structure, is another aspect of silicon-induced mechanical defense. In particular, arabinan side chains of rhamnogalacturonan I increased in some vessel walls and galactan side chains of rhamnogalacturonan I increased in the xylem parenchyma, increasing the mechanical strength of the host against infection (Diogo and Wydra, 2007). Si application increased the cell wall lignin content which made it hard for dispersion of fungal mycelium (Polanco et al., 2012). Silicon-treated plants increased resistance against infections by forming electron-dense layers along primary and secondary cell walls as well as over pit membranes of xylem vessels (Chérif et al., 1994b) making it harder for fungal permeation and dispersion within the plant body.

\section{Biochemical resistance}

Silicon-mediated defense reaction is induced in fruits and vegetables by synthesis of secondary metabolites. Secondary 
metabolites influence the interactions between plants and the organisms that inhabit their environment: insects and other animals, microbes and fungi. They are obnoxious, repellent or downright toxic to biotic attackers of plants (Delhaize et al., 1993). Antioxidant enzymes, phenolic compounds, chitinases and phytoalexins are the common secondary metabolites found related to chemical defense in fruits and vegetables.

\section{Acquired resistance through antioxidant enzymes}

Several studies showed that lowering disease severity in the Sitreated plants was in line with higher activity of antioxidant defense enzymes in particular, superoxide dismutase, catalase, peroxidase, ascobate peroxidase, guaiacol peroxidase, $\beta$-1, 3-glucanase and glutathione reductase. Plants protect cell and sub cellar systems from the cytotoxic effects of the active oxygen radicals using antioxidant enzymes. Silicon was said to be effective in controlling pre harvest diseases of fruits and vegetables as a result of these antimicrobial enzymes (Wei et al., 2004; Cherif et al., 1994b; Liang et al., 2005). A significant reduction in postharvest diseases by silicon application was noted with respect to enhanced defensive enzyme activity (Qin and Tian, 2005; Bi et al., 2006; Guo et al, 2007; Liu et al., 2009, 2010; Kumar and McConchie, 2010; Li et al., 2012; Ebrahimi et al., 2012; Polanco et al., 2012; Farahani et al., 2013; Polanco et al., 2014; Kurabachew and Wydra, 2014). Rootapplied Si significantly enhanced the activities of defensive enzymes, for example catalase, peroxidase, polyphenoloxidase and $\beta-1,3-$ glucanase in two asparagus cultivars, UC157 and Gynlim against stem blight caused by Phomopsis asparagi (Lu et al., 2008).

\section{Synthesis}

Silicon could be used to reduce many fungal diseases mildew (Powdery mildew and downy mildew), rots (fusarium root rot, phytophthora root rot, pink rot), mould (Blue mould, green mould, gray mould, white mould), blight (phytophthora blight and stem blight), and wilt (fusarium wilt, and anthracnose) in tropical fruits and vegetables. A few bacterial diseases (bacterial wilt) were also reduced by application of silicon. Many diseases observed in tropical fruits and vegetable were significantly reduced by silicon 
application. However, gray mould in strawberry and blue mould diseases in some fruits grown in temperate countries (sweet cherry, peach, Jujube, apple, pear, oranges etc) were reduced by application of Silicon.

When considering the types of diseases and resistance enhanced by application of silicon in tropical fruits and vegetables, many records (75\% of the published records) were available on reducing the powdery mildew disease in cucumber, muskmelon, Zucchini squash, pumpkin and about $25 \%$ of the published findings were available on reducing powdery mildew in disease in strawberry and grapes.

Silicon has been applied as a form of pre or post-harvest to reduce diseases in green mould or gray mould. But the postharvest application was done for reducing blue mould disease.

Foliar application of silicon has been used most effectively to reduce powdery mildew disease. However, blight disease was controlled by application of foliar or root.

The possible mechanism/s on diseases reduced by silicon could possibly be due to the formation of physical barriers by silicon depositions or by biochemical compounds formed or antioxidant defense enzymes formed.

Pre-harvest or post-harvest silicon application had shown a great potential in controlling diseases by inhibiting or delaying the growth and development of the mycelium of the pathogen. Powdery mildew infected leaf cells of silicate treated plants were exhibited to have extensive silica polymerization enhancing the thickness against the fungi in the halo region surrounding the site of fungal penetration

\section{Conclusions}

Silicon has proven to be an effective means of reducing diseases in tropical fruits and vegetables. Therefore, the use of silicon could reduce the use of fungicides for controlling diseases. 
The remarked alleviative effect of $\mathrm{Si}$ was recorded in controlling powdery mildew in cucurbits. Silicon might be effective in suppressing diseases in fruits and vegetables than bacterial diseases since preponderance of the findings were related to $\mathrm{Si}$ mediated fungal diseases than bacterial diseases. Silicon-induced resistance against infections is mainly attributed to the mechanical and chemical defense. In addition, SAR like mechanisms were involved in silicon induced defense in fruits and vegetables.

\section{References}

Abraham, A. O. (2010). Integrated use of yeast, hot water and potassium silicate treatments for the control of postharvest green mould of citrus and litchi (Doctoral dissertation).

Anderson, J. M., Pegg, K. G., Dann, E. K., Cooke, A. W., Smith, L. A., Willingham, S. L., Giblin, F. R., Dean, J. R. \& Coates, L. M. (2005). New strategies for the integrated control of avocado fruit diseases. In: New Zealand and Australia Avocado Growers' Conference.5: Pp. 1-6.

Bekker, T. F., Labuschagne, N., Aveling, T. \& Kaiser, C. (2007). Efficacy of water soluble potassium silicate against Phytophthora root rot of avocado under field conditions. South African Avocado Growers' Association 30: 39-48.

Belanger, R. R., Bowen, P. A., Ehret, D. L. \& Menzies, J. G. (1995). Soluble silicon: its role in crop and disease management of greenhouse crops. Plant Disease 79(4): 329-336.

https://doi.org/10.1094/PD-79-0329

Bi, Y., Tian, S. P., Guo, Y. R., Ge, Y. H. \& Qin, G. Z. (2006). Sodium silicate reduces postharvest decay on Hami melons induced resistance and fungistatic effects. Plant disease 90(3): 279283. https://doi.org/10.1094/PD-90-0279

Blaich, R. \& Grundhofer, H. (1998). The influence of silica fertilization on the resistance of grapevines to powdery mildew. Vitis 37(1): 21-26. 
Bosse, R. J., Bower, J. P. \& Bertling, I. (2011). Pre-and post-harvest treatments on Fuerte avocados to control anthracnose (Colletotrichum gloeosporioides) during ripening. South African Avocado Growers' Association 34: 65-69.

Bowen, P., Menzies, J. \& Ehret, D. (1992). Soluble silicon sprays inhibit powdery mildew development on grape leaves. Journal of the American Society for Horticultural Science 117(6): 906912.

Buttaro, D., Bonasia, A., Minuto, A., Serio, F. \& Santamaria, P. (2009). Effect of silicon in the nutrient solution on the incidence of powdery mildew and quality traits in Carosello and Carattiere (Cucumis melo L.) Grown in a soilless system. Journal of Horticultural Science and Biotechnology 84(3): 300304. https://doi.org/10.1080/14620316.2009.11512521

Chen, N. L., Hu, M., Qiao, C. P., Nai, X. Y. \& Wang, R. (2010). Effects of BTH, SA, and $\mathrm{SiO}_{2}$ treatment on disease resistance and leaf HRGP and lignin contents of melon seedlings. Scientia Agricultura Sinica 3: 014.

Cherif, M. \& Belanger, R. R. (1992). Use of potassium silicate amendments in recirculating nutrient solutions to suppress Phythium ultimum on long English cucumber. Plant Disease 76: 1008-1011. https://doi.org/10.1094/PD-76-1008

Chérif, M., Asselin, A. \& Bélanger, R. R. (1994a). Defense responses induced by soluble silicon in cucumber roots infected by Pythium spp. Phytopathology 84(3): 236-242.

https://doi.org/ 10.1094/Phyto-84-236

Chérif, M., Menzies, J. G., Ehret, D. L., Bogdanoff, C. \& Bélanger, R. R. (1994b). Yield of cucumber infected with Pythium aphanidermatum when grown with soluble silicon. Horticultural Science 29(8): 896-897. 
Dannon, E. A. \& Wydra, K. (2004). Interaction between silicon amendment, bacterial wilt development and phenotype of Ralstonia solanacearum in tomato genotypes. Physiological and Molecular Plant Pathology 64(5): 233-243.

https://doi.org/10.1016/j.pmpp.2004.09.006

David, D. \& Weerahewa, H. L. D. (2012). Silicon suppresses anthracnose diseases in tomato (Lycopersicon esculentum) by enhancing disease resistance. Proceedings of $8^{\text {th }}$ Annual Sessions of The Open University of Sri Lanka, Nawala, Sri Lanka. 299-302.

Delhaize, E., Ryan, P. R., \& Randall, P. J. (1993). Aluminum tolerance in wheat (Triticum aestivum L.) II. Aluminum stimulated Excretion of malic acid from root apices. Plant Physiology 103:695-702.

https://doi.org/10.1104/pp.103.3.695

Diogo, R. V. \& Wydra, K. (2007). Silicon-induced basal resistance in tomato against Ralstonia solanacearum is related to modification of pectic cell wall polysaccharide structure. Physiological and Molecular Plant Pathology 70(4): 120-129. https://doi.org/10.1016/j.pmpp.2007.07.008

Ebrahimi, L., Aminian, H., Etebarian, H. R. \& Sahebani, N. (2012). Control of apple blue mould disease with Torulaspora delbrueckii in combination with Silicon. Archives of Phytopathology and Plant Protection 45(17): 2057-2065.

https://doi.org/10.1080/03235408.2012.720772

Ebrahimi, L., Etebarian, H. R., Aminian, H. \& Sahebani, N. (2013). Biological control of apple blue mould disease with Metschnikowia pulcherrima alone and in combination with silicon and its mechanisms of antagonism. Iranian Journal of Plant Pathology 49(1): 39-40.

El-Samman, M. G., El-Sawy, M., Francis, R. R., El-Borollosy, M. A. \& Hosni, A. M. (2000). The role of soluble silicon in controlling some root rot diseases of cucumber and tomato. In: Proceedings of the Eighth Conference of Agricultural 
Development Research, Ain Shams University, Cairo, Egypt, 20-22 November 2000 4: 1411-1419.

Epstein, E. (1999). Silicon. Annual Review of Plant Biology 50(1): 641-664. https://doi.org/10.1146/annurev.arplant.50.1.641

Etebarian, H. R., Farhangian, S. \& Ebrahimi, L. (2013). Combination of silicon and hot water to control of postharvest blue mould caused by Penicillium expansum in apple. International Journal of Agriculture: Research and Review 3(1): 72-79.

Farahani, L., Etebarian, H. R., Sahebani, N. \& Aminian, H. (2012). Biocontrol of blue mould of apple by Candida membranifaciens in combination with silicon. Archives of Phytopathology and Plant Protection 45(3): 310-317.

Farahani, L., Etebarian, H. R., Sahebani, N. \& Aminian, H. (2013). Induction of defense responses in apple fruit treated with Pichia guilliermondii and silicon against Penicillium expansum. International Journal of Agronomy and Plant Production 4(1): 1-6. https://doi.org/10.1080/03235408.2011.559055

Fatema, K., Hall, A., Orson, J., Bush, M., Cook, S., Boys, E. \& Cussans, J. (2011). Study the role of silicon in strawberries and its possible role in control of strawberry powdery mildew. Aspects of Applied Biology 106: 233-239.

Fawe, A. B. O. U. Z. A. I. D., Abou-Zaid, M., Menzies, J. G. \& Bélanger, R. R. (1998). Silicon-mediated accumulation of flavonoid phytoalexins in cucumber. Journal of Phytopathology 88(5): 396-401. https://doi.org/10.1094/PHYTO.1998.88.5.396

Fortunato, A. A., Rodrigues, F. Á. \& do Nascimento K. J. T. (2012). Physiological and biochemical aspects of the resistance of banana plants to fusarium wilt potentiated by silicon. Journal of Phytopathology 102(10): 957-966. 
https://doi.org/10.1094/PHYTO-02-12-0037-R

French-Monar, R. D., Rodrigues, F. A., Korndörfer, G. H. \& Datnoff, L. E. (2010). Silicon suppresses phytophthora blight development on bell pepper. Journal of Phytopathology 158(8): 554-560.

https://doi.org/10.1111/j.1439-0434.2009.01665.x

Garibaldi, A., Gilardi, G., Cogliati, E. E. \& Gullino, M. L. (2012). Silicon and increased electrical conductivity reduce downy mildew of soilless grown lettuce. European Journal of Plant Pathology 132(1): 123-132.

https://doi.org/10.1007/s10658-011-9855-6

Ghareeb, H., Bozsó, Z., Ott, P. G., Ripening, C., Stahl, F. \& Wydra, K. (2011). Transcriptome of silicon-induced resistance against Ralstonia solanacearum in the silicon nonaccumulator tomato implicates priming effect. Physiological and Molecular Plant Pathology 75(3): 83-89.

https://doi.org/10.1016/j.pmpp.2010.11.004

Guo, Y. R., Ge, Y. H., Bi, Y. \& Zhao, H. (2003). Effect of postharvest sodium silicate treatment on Alternaria rot of pingguoli. Food Science 12: 036.

https://doi.org/10.1111/j.1365-2621.2006.01464.x

Guo, Y., Liu L., Zhao, J. \& Bi, Y. (2007). Use of silicon oxide and sodium silicate for controlling Trichothecium roseum postharvest rot in Chinese cantaloupe (Cucumis melo L.). International Journal of Food Science and Technology 42(8):1012-1018.

Guo, Y. R., Zhao, H., Chen, D. R., Liu, L. \& Bi, Y. (2005). Inhibitory mechanisms of two silicon compounds on mildew powder of melon. Scientia Agricultura Sinica 38: 25.

Heckman, J. R., Johnston, S. \& Cowgill, W. (2003). Pumpkin yield and disease response to amending soil with silicon. Horticultural Science 38(4): 552-554. 
Heine, G., Tikum, G. \& Horst, W. J. (2007). The effect of silicon on the infection by and spread of Pythium aphanidermatum in single roots of tomato and bitter gourd. Journal of Experimental Botany 58(3): 569-577. https://doi.org/10.1093/jxb/er1232

Hu, X. J. \& Zhu, Z. J. (2008). Effects of silicon on resistance of powdery mildew and the activities of antioxidative enzymes in leaf apoplast of cucumber. Acta Agriculturae Zhejiangensis 20(1): 67.

Huang, C. H., Roberts, P. D. \& Datnoff, L. E. (2011). Silicon suppresses Fusarium crown and root rot of tomato. Journal of Phytopathology 59(7-8): 546-554. https://doi.org/10.1111/j.1439-0434.2011.01803.x

Jayawardana, H. A. R. K., Weerahewa, H. L. D. \& Saparamadu, M. D. J. S. (2014). Effect of root or foliar application of soluble silicon on plant growth, fruit quality and anthracnose development of capsicum. Tropical Agricultural Research 26(1): 74-81. https://doi.org/10.4038/tar.v26i1.8073

Jayawardana, H. A. R. K., Weerahewa H. L. D. and Saparamadu, M. D. J. S. (2016). Rice hull as a silicon source in simplified hydroponic system to enhance anthracnose disease resistance and some growth and fruit parameters of capsicum. International Journal of Recycling of Organic Waste in Agriculture. 5:9-15. DOI 10.1007/s40093-015-0112-4.

Jayawardana, H. A. R. K. ., Weerahewa H. L. D. and Saparamadu, M. D. J. S. (2015). Enhanced resistance against anthracnose disease in Capsicum annum by amendment of nutrient solution with silicon. Journal of Horticultural Science and Biotechnology 90 (5) 557-562.

DOI:10.1080/14620316.2015.11668714

JungSup, L., JongHan, P., MyeongSun, Y. \& SeonKyu, K. (2000). Effect of soluble silicon on the severity of powdery mildew 
(Sphaerotheca fuliginea) in cucumber leaves. Journal of the Korean Society for Horticultural Science 41(4): 356-360.

Kablan L, Lagauche A, Delvaux B, Legrève A. (2012). Silicon reduces black sigatoka development in banana Plant Disease, 96: 273-278. https://doi.org/10.1094/PDIS-04-11-0274

Kanto, T., Maekawa, K. \& Aino, M. (2007). Suppression of conidial germination and appressorial formation by silicate treatment in powdery mildew of strawberry. Journal of General Plant Pathology 73(1): 1-7. https://doi.org/10.1007/s10327-0060311-y

Kanto, T., Miyoshi, A., Ogawa, T., Maekawa, K. \& Aino, M. (2004). Suppressive effect of potassium silicate on powdery mildew of strawberry in hydroponics. Journal of General Plant Pathology 70(4): 207-11. https://doi.org/10.1007/s10327-004-0117-8

Khoshgoftarmanesh, A. H., Mohaghegh, P., Sharifnabi, B., Shirvani, M. \& Khalili, B. (2012). Silicon nutrition and Phytophthora drechsleri infection effects on growth and mineral nutrients concentration, uptake, and relative translocation in hydroponic-grown cucumber. Journal of Plant Nutrition 35(8): 1168-79. https://doi.org/10.1080/01904167.2012.676129

Kiirika, L. M., Stahl, F. \& Wydra, K. (2013). Phenotypic and molecular characterization of resistance induction by single and combined application of chitosan and silicon in tomato against Ralstonia solanacearum. Physiological and Molecular Plant Pathology 81: 1-12.

https://doi.org/10.1016/j.pmpp.2012.11.002

Kumar, V. \& Mcconchie, R. (2010). Involvement of antifungal compounds from rockmelon fruit rind (Cucumis melo L.) In resistance against the fruit rot pathogen Fusarium oxysporum f. Sp. Melonis. European Journal of Plant Pathology 126(4): 531-540. https://doi.org/10.1007/s10658-009-9562-8

Kurabachew, H. \& Wydra, K. (2014). Induction of systemic resistance and defense-related enzymes after elicitation of 
resistance by rhizobacteria and silicon application against Ralstonia solanacearum in tomato (Solanum lycopersicum). Crop Protection 57: 1-7. https://doi.org/10.1016/j.cropro.2013.10.021

Lee, J. S., Seo, S. T., Wang, T. C., Jang, H. I., Pae, D. H. \& Engle, L. M. (2004). Effect of potassium silicate amendment in nutrient solutions to suppress Phtophthora blight (Phytophtora capsici) in pepper (Capsicum annuum). The World Vegetable Center 42: 741 .

Li, W., Bi, Y., Ge, Y., Li, Y., Wang, J. \& Wang, Y. (2012). Effects of postharvest sodium silicate treatment on pink rot disease and oxidative stress-antioxidative system in muskmelon fruit. European Food Research and Technology 234(1): 137-145. https://doi.org/10.1007/s00217-011-1611-9

Li, Y. H., Bi, Y., Zhang, H. Y., Ge, Y. H. \& Liu, J. (2008). Inhibiting effect of postharvest sodium silicate treatment on blue mould of pear (cv. Pingguoli). Journal of Gansu Agricultural University 6: 33.

Liang, Y. C., Sun, W. C., Si, J. \& Römheld, V. (2005). Effects of foliar-and root-applied silicon on the enhancement of induced resistance to powdery mildew in Cucumis sativus. Plant Pathology 54(5): 678-685.

https://doi.org/10.1111/j.1365-3059.2005.01246.x

Liu, J., Zong, Y., Qin, G., Li, B., \& Tian, S. (2010). Plasma membrane damage contributes to antifungal activity of silicon against Penicillium digitatum. Current microbiology 61(4): 274-9. https://doi.org/10.1007/s00284-010-9607-4

Liu, L., Guo, Y., Bi, Y., Li, M., Zhao, J. \& Zhao, H. (2009). Inhabited mechanisms of silicon compounds against Fusarium rot (Fusarium spp.) of postharvest Chinese cantaloupe. Journal of Food Processing and Preservation 33(s1): 187-202.

https://doi.org/10.1111/j.1745-4549.2008.00292.x 
Lopes, U. P., Zambolim, L., Costa, H., Pereira, O. L. \& Finger, F. L. (2014). Potassium silicate and chitosan application for gray mould management in strawberry during storage. Crop Protection 63: 103-106.

https://doi.org/10.1016/j.cropro.2014.05.013

Lu, G., Jian, W., Zhang, J., Zhou, Y. \& Cao, J. (2008). Suppressive effect of silicon nutrient on Phomopsis stem blight development in asparagus. Horticultural Science 43(3): 811817.

Ma, J. F. (2004). Role of silicon in enhancing the resistance of plants to biotic and abiotic stresses. Soil Science and Plant Nutrition 50(1): 11-18.

https://doi.org/10.1080/00380768.2004.10408447

Ma, J. F. \& Takahashi, E. (2002). Soil, fertilizer, and plant silicon research in Japan, $1^{\text {st }}$ edition, Elsevier Science, Amsterdam, The Netherlands.5-85. https://doi.org/10.1016/B978-044451166-9/50002-6

Menzies, J., Bowen, P. \& Ehret, D. (1992). Foliar application of potassium silicate reduces severity of powdery mildew on cucumber, muskmelon, and zucchini squash. Journal of the American Society for Horticultural Science 117(6): 902-905.

Menzies, J. G., Ehret, D. L., Glass, A. D. M. \& Samuels, A. L. (1991b). The influence of silicon on cytological interactions between Sphaerotheca fuliginea and Cucumis sativus. Physiological and Molecular Plant Pathology 39: 403-414. https://doi.org/10.1016/0885-5765(91)90007-5

Menzies, J. G., Ehret, D. L., Glass, A. D. M., Helmer, T., Koch, C. \& Seyward, F. (1991a). Effects of soluble silicon on the parasitic fitness of Sphaerotheca fuliginea. Phytopathology 81: 84-88. https://doi.org/10.1094/Phyto-81-84 
Mersha, Z., Zhang, S. \& Mo, X. (2012). Evaluation of SAR inducers, chitosan, and silicon for control of Phytophthora blight of tomato. Phytopathology 102(7): 80-80.

Mkhize, N., Bower, J. P., Bertling, I. \& Mathaba, N. (2013). Response of citrus physiology to phosphorus acid and silicon as elicitors of induced disease resistance. Acta Horticulturae. (ISHS) 1007: 135-141

https://doi.org/10.17660/ActaHortic.2013.1007.12

Mohaghegh, P., Khoshgoftarmanesh, A. H., Shirvani, M., Sharifnabi, B. \& Nili, N. (2011). Effect of silicon nutrition on oxidative stress induced by Phytophthora melonis infection in cucumber. Plant Disease 95(4): 455-460.

https://doi.org/10.1094/PDIS-05-10-0379

Moraes, S. R., Pozza, E. A., Alves, E., Pozza, A. A., Carvalho, J. G., Lima, P. H. \& Botelho, A. O. (2006). Effects of silicon sources on the incidence and severity of the common beans anthracnose. Fitopatologia Brasileira 31(1): 69-75.

https://doi.org/10.1590/S0100-41582006000100012

Moscoso-Ramírez, P. A. \& Palou, L. (2014). Preventive and curative activity of postharvest potassium silicate treatments to control green and blue moulds on orange fruit. European Journal of Plant Pathology: 138(4): 721-732.

https://doi.org/10.1007/s10658-013-0345-x

O'Neil, T. M. (1991). Investigation of glasshouse structure, growing medium and silicon nutrition as factors affecting disease incidence in cucumber crops. Mededelingen van de Faculteit Landbouwwetenschappen, Rijksuniversiteit Gent 56(2b): 359367.

Palmer, S., Scott, E., Stangoulis, J. \& Able, A. J. (2006). The effect of foliar-applied $\mathrm{Ca}$ and $\mathrm{Si}$ on the severity of powdery mildew in two strawberry cultivars. Acta Horticulturae (ISHS) 708: 135-140. https://doi.org/10.17660/ActaHortic.2006.708.21 
Paulajúnior, T. J., Vieira, R. F., Teixeira, H. \& Carneiro, J. E. S. (2009). Foliar application of calcium chloride and calcium silicate decreases white mould intensity on dry beans. Tropical Plant Pathology 34(3): 171-174.

Polanco, L. R., Rodrigues, F. A., Nascimento, K. J. T., Shulman, P., Silva, L. C., Neves, F. W. \& Vale, F. X. R. (2012). Biochemical aspects of bean resistance to anthracnose mediated by silicon. Annals of Applied Biology 161(2): 140-150. https://doi.org/10.1111/j.1744-7348.2012.00558.x

Polanco, L. R., Rodrigues, F. A., Nascimento, K. J., Cruz, M. F., Curvelo, C. R., DaMatta, F. M. \& Vale, F. X. (2014). Photosynthetic gas exchange and antioxidative system in common bean plants infected by Colletotrichum lindemuthianum and supplied with silicon. Tropical Plant Pathology 39(1): 35-42.

https://doi.org/10.1590/S1982-56762014000100005

Prokkola, S. \& Kivijärvi, P. (2008). Effect of biological sprays on the incidence of grey mould, fruit yield and fruit quality in organic strawberry production. Agricultural and Food Science 16(1): 25-33 https://doi.org/10.2137/145960607781635886

Qin, G. Z. \& Tian, S. P. (2005). Enhancement of biocontrol activity of Cryptococcus laurentii by silicon and the possible mechanisms involved. Phytopathology 95(1): 69-75. https://doi.org/10.1094/PHYTO-95-0069

QiuJu, Y., XiaoWei, Z., WuSheng, J. \& GuoQiang, W. (2009). Influences of silicon on phenylalanine metabolism in cucumber leaves and its relation to resistance to powdery mildew. Journal of Jilin Agricultural University 31(1): 16-21.

Reynolds, A. G., Veto, L. J., Sholberg, P. L., Wardle, D. A. \& Haag, P. (1996). Use of Potassium silicate for the control of powdery mildew [Uncinula necator (Schwein) Burrill] in Vitisvinifera L. Cultivar Bacchus. American Journal of Enology and Viticulture: 47(4): 421-428. 
Rodrigues, F. A., Duarte, H. S. S., Rezende, D. C., Filho, J. W., Korndörfer, G. H., \& Zambolim, L. (2010). Foliar spray of potassium silicate on the control of angular leaf spot on beans. Journal of Plant Nutrition 33(14): 2082-2093.

https://doi.org/10.1080/01904167.2010.519082

Safari, S., Soleimani, M. J. \& Zafari, D. (2012). Effects of silicon pretreatment on the activities of defense-related enzymes in cucumber inoculated with Fusarium oxysporum. Advances in Environmental Biology 6(12): 4001-4007.

Samuels, A. L., Glass, A. D. M., Ehret, D. L. \& Menzies, J. G. (1993). The effects of silicon supplementation on cucumber fruit: changes in surface characteristics. Annals of Botany 72(5): 433-440. https://doi.org/10.1006/anbo.1993.1129

Samuels, A. L., Glass, A. D. M., Menzies, J. G. \& Ehret, D. L. (1994). Silicon in cell walls and papillae of Cucumis sativus during infection by Sphaerotheca fuliginea. Physiological and Molecular Plant Pathology 44(4): 237-242.

https://doi.org/10.1016/S0885-5765(05)80027-X

Schuerger, A. C. \& Hammer, W. (2003). Suppression of powdery mildew on greenhouse-grown cucumber by addition of silicon to hydroponic nutrient solution is inhibited at high temperature. Plant Disease 87(2): 177-185.

https://doi.org/10.1094/PDIS.2003.87.2.177

Shiping, T., Guozheng, Q. \& Yong X. (2005). Synergistic effects of combining biocontrol agents with silicon against postharvest diseases of jujube fruit. Journal of Food Protection 68(3): 544550. https://doi.org/10.4315/0362-028X-68.3.544

Somapala, K. S., Weerahewa, H. L. D. and Thrikawala, S. (2016). Silicon rich rice hull amended soil enhances anthracnose resistance in tomato. Proceedia Food Science. 6:190-193. DOI: $10.1016 /$ j.profoo.2016.02.046 
https://doi.org/10.1016/j.profoo.2016.02.046

Vermeire M-L, Kablan L, Dorel M, Delvaux B, Risède J-M, Legrève, A. 2011. Protective role of silicon in the bananaCylindrocaldium spathiphylli pathosystem. European Journal of Plant Pathology, 131: 621-630

https://doi.org/10.1007/s10658-011-9835-x

Wang, S. Y. \& Galletta, G. J. (1996). Effect of silicon on strawberry plants. Horticultural Science 31(4): 675-675.

Wang, L., Cai, K., Chen, Y. \& Wang, G. (2013). Silicon-mediated tomato resistance against Ralstonia solanacearum is associated with modification of soil microbial community structure and activity. Biological Trace Element Research 152(2): 275-283.

https://doi.org/10.1007/s12011-013-9611-1

Wei, G., Zhu, Z., Li, J. \& Yao, Q. (2004). Effects of silicon supply and Sphaerotheca fuliginea inoculation on resistance of cucumber seedlings against powdery mildew. The Journal of Applied Ecology 15(11): 2147.

Weerahewa D. and David D. (2015). Effect of Silicon and potassium on tomato anthracnose and on postharvest quality of tomato fruit (Lycopersicon esculentum Mill.) Journal of National Science Foundation. 43 (3):271-278.

DOI:http://dx.doi.org/10.4038/jnsffr.v4313.7959.

Wolff, S. A., Karoliussen, I., Rohloff, J. \& Strimbeck, R. (2012). Foliar applications of silicon fertilizers inhibit powdery mildew development in greenhouse cucumber. Journal of Food, Agriculture and Environment 10(1): 355-359.

Yanar, Y., Yanar, D. \& Gebologlu, N. (2013). Control of powdery mildew (Leveillula taurica) on tomato by foliar sprays of liquid potassium silicate $\left(\mathrm{K}_{2} \mathrm{SiO}_{3}\right)$. African Journal of Biotechnology 10(16): 3121-3123. 
Yang, L., Zhao, P., Wang, L., Filippus, I. \& Meng X. (2010). Synergistic effect of oligochitosan and silicon on inhibition of Monilinia fructicola infections. Journal of the Science of Food and Agriculture 90(4): 630-634.

Yang, X., Feng, H. X. \& Yang, Y. S. (2008). Effects of silicon on flowering Chinese cabbage's anthracnose occurrence, flower stalk formation, and silicon uptake and accumulation. The Journal of Applied Ecology 19(5): 1006.

Yu, Y. \& Du, X. G. (2009). The inhibitory effect and mechanism of calcium and silicon solutions on cucumber downy mildew. Northern Horticulture 10: 041.

Yu, Y., Schjoerring J. K. \& Du, X. (2010). Effects of silicon on the activities of defense-related enzymes in cucumber inoculated with Pseudoperonospora cubensis. Journal of Plant Nutrition 34(2):243-247.

https://doi.org/10.1080/01904167.2011.533325

Yurong, G., Derong, C., Yang, B., Hua, Z. \& Xinsheng, L. (2005). Inhibitive effect of silicon compounds on powdery mildew of muskmelon. Journal of Fruit Science 1: 8.

Yurong, G., Yang, B. \& Ziyi, C. (2003). Inhibiting muskmelon pink mould rot of cantaloupe 'Yujinxiang' treated with silicon agents. Acta Horticulturae Sinica 5: 022 
